\title{
Information for Our International Colleagues
}

In this Global Theme Issue, we would like to take the opportunity to welcome international readers, authors, and peer reviewers. Below are some items of information that should be useful to our colleagues in other countries.

\section{Expedited International Access (EID)}

EID provides faster access to the fournal of the Board of Family Medicine ( $7 A B F M)$ Online for users from certain countries outside of the United States and Canada. Using a special private line (http:// intl.jabfm.org) to access $7 A B F M$ Online from the following countries provides a consistency and reliability advantage: Australia, Brazil, China, France, Germany, Hong Kong, Ireland, Israel, Italy, Japan, Mexico, Russia, Singapore, South Africa, South Korea, Spain, Sweden, Switzerland, Taiwan, The Netherlands, and United Kingdom. Do not use this service unless you are in one of these locations. More information about EID is located at the bottom of the $7 A B F M$ home page (www.jabfm.org).

\section{International Licensing and Translations of JABFM Content}

Having received numerous requests over the years for permission to reprint articles in foreign languages, $7 A B F M$ decided to formalize the request process and to actively market $\mathcal{A} A B F M$ to overseas publishers who might be interested in performing their own translation and publishing services. To that end, a contractual relationship has begun with Healthy Impressions, Inc, of Florida, to represent $7 A B F M$ to foreign publishers in the sublicensing of non-English editions of $7 A B F M$ issues or specific articles. Articles translated locally for printing in the United States will still be handled through the 7ABFM editorial office (jabfm@med.wayne.edu). Thus far, Healthy Impressions has signed 2 agreements to provide for the publication of the $7 A B F M$ in Turkey and in southeast Asia including China and Japan. The publisher in Asia is Ezyhealth Holdings PTE, Ltd, and the publisher in Turkey is YUCE reklam/yayim/dagitim a.s. In addition, through an arrangement with Ovid Technologies, $7 A B F M$ has granted an online subscription license to the National Health Service in the United Kingdom.

\section{Invitation to International Authors and Peer Reviewers}

FABFM encourages manuscript submissions from international authors. All manuscripts are peer reviewed and evaluated on the extent to which they represent original work, provide new knowledge, are significant to the advancement of family medicine, and are of interest to family physicians and primary care researchers. ${ }^{1,2}$ FABFM also has a feature titled "Family Medicine - World Perspective," which reports on the practice or education of family physicians around the world.

We also welcome new peer reviewers. ${ }^{3,4}$ To join the $7 A B F M$ reviewer database, please complete the peer reviewer volunteer form available at http://www.jabfm.org/misc/PeerReviewers.shtml and fax to (313) 577-9828 or e-mail to jabfm@ med.wayne.edu.

Anne Victoria Neale, PhD, MPH, Deputy Editor Marjorie A. Bowman, MD, MPA, Editor

\section{References}

1. Bowman M, Neale AV. The next iteration of The Fournal of the American Board of Family Practice. J Am Board Fam Pract 2003;16(4):352-4.

2. Neale AV, Schwartz KL. FABFP listens and sets research agenda: report from the NAPCRG Annual Meeting. J Am Board Fam Pract 2003;16(6):562-3.

3. Neale AV, Bowman MA. Peer review process of the 7ABFM. J Am Board Fam Med 2006;19(2):209-10.

4. Neale AV, Schwartz KL, Bowman MA. Peer reviewing for the Fournal of the American Board of Family Medicine: what does it take? J Am Board Fam Med 2006;19(6):643-7.

doi: 10.3122/jabfm.2007.06.070191 